DOI: https://doi.org/10.47405/mjssh.v6i7.920

\begin{tabular}{|c|c|}
\hline 4 & Malaysian Journal of Social Sciences and Humanities (MJSSH) \\
\hline $\begin{array}{l}\text { Malaysian Journa of } \\
\text { Social cciences and }\end{array}$ & Volume 6, Issue 7, July 2021 \\
\hline (MJ-sSH) & e-ISSN : 2504-8562 \\
\hline & $\begin{array}{l}\text { Journal home page: } \\
\text { www.msocialsciences.com }\end{array}$ \\
\hline
\end{tabular}

\title{
Pembelajaran Sejarah Berasaskan Penggunaan Platform Google Classroom dan Aplikasi Kemahiran 4K
}

\author{
M. Kaviza ${ }^{1}$ \\ Correspondence: M. Kaviza (kavizakaviza@yahoo.com)
}

\begin{abstract}
Abstrak
Kajian berbentuk tinjauan ini bertujuan untuk mengenal pasti tahap persepsi murid terhadap pelaksanaan aktiviti pembelajaran sejarah melalui penggunaan platform Google Classroom dan aplikasi kemahiran $4 \mathrm{~K}$ berdasarkan jantina. Seramai 41 orang murid tingkatan dua terlibat dalam kajian yang ditentukan berdasarkan teknik persampelan berkelompok. Instrumen kajian ini merupakan soal selidik skala 5 likert yang telah disahkan oleh pakar penilai dan mempunyai nilai ketekalan yang baik. Data kajian ini telah dianalisis secara deskriptif dan inferensi iaitu ujian-t sampel tak bersandar dengan menggunakan perisian IBMSPSS versi 24. Dapatan kajian ini telah melaporkan bahawa tahap persepsi murid terhadap pelaksanaan aktiviti pembelajaran sejarah melalui penggunaan platform Google Classroom dan aplikasi kemahiran $4 \mathrm{~K}$ adalah tinggi. Selain itu, tahap persepsi murid terhadap pelaksanaan aktiviti pembelajaran sejarah melalui penggunaan platform Google Classroom dan aplikasi kemahiran $4 \mathrm{~K}$ juga dilaporkan berada pada tahap tinggi dalam kalangan murid lelaki dan murid perempuan. Walau bagaimanapun, dapatan kajian ini telah melaporkan bahawa tidak terdapat perbezaan min yang signifikan bagi persepsi murid terhadap pelaksanaan aktiviti pembelajaran sejarah melalui penggunaan platform Google Classroom dan aplikasi kemahiran $4 \mathrm{~K}$ berdasarkan jantina. Implikasi kajian ini telah membuka ruang cadangan kepada para guru sejarah untuk mereka bentuk dan melaksanakan aktiviti pembelajaran sejarah dengan menggunakan platform Google Classroom dan mengaplikasikan kemahiran 4K iaitu kemahiran berfikir kritis, kemahiran berfikiran kreatif, kemahiran kolaborasi dan kemahiran komunikasi dalam proses pembelajaran dan pemudahcaraan bagi mata sejarah dengan lebih meluas.
\end{abstract}

Kata kunci: platform Google Classroom, kemahiran 4K, mata pelajaran sejarah, persepsi, murid tingkatan dua

\section{History Learning Based on the Use of Google Classroom Platform and 4C Skills Application}

\begin{abstract}
This survey study aims to identify the level of students' perceptions of the implementation of history learning activities through the use of Google Classroom platform and 4C skills application based on gender. A total of 41 form two students were involved in the study which was determined based on cluster sampling technique. The instrument of this study is a likert scale questionnaire that has been validated by expert evaluators and has a good consistency value. The data of thisu study were analyzed descriptively and inferentially, such as independent sample t-test using IBM SPSS software version 24. The findings of this study have reported that the level of students' perception of the implementation of
\end{abstract}


history learning activities through the use of the Google Classroom platform and $4 \mathrm{C}$ skills application is high. In addition, the level of students' perception on the implementation of history learning activities through the use of the Google Classroom platform and 4C skills application was also reported at high level among male and female students. However, the findings of this study have reported that there is no significant mean difference for students' perceptions of the implementation of history learning activities through the use of Google Classroom platform and 4C skills application based on gender. The implications of this study have opened a space of suggestions for history teachers to design and implement history learning activities using the Google Classroom platform and apply 4C skills, namely critical thinking skills, creative thinking skills, collaboration skills and communication skills in the learning and facilitation process more widely.

Keywords: Google Classroom platform, 4C skills, history subjects, perception, form two students

\section{Pengenalan}

Kementerian Pendidikan Malaysia melalui Pelan Pembangunan Pendidikan Malaysia 2013-2025 telah menekankan amalan pembelajaran dan pemudahcaraan murid berasaskan pelaksanaan pembelajaran abad ke-21 yang melibatkan satu set kemahiran belajar yang bersifat berpusatkan murid (Kementerian Pendidikan Malaysia (KPM), 2013). Penekanan amalan pembelajaran ini juga tidak ketinggalan dalam proses pembelajaran dan pemudahcaraan mata pelajaran sejarah yang bertujuan untuk memberi kefahaman mengenai masyarakat, negara Malaysia dan dunia dengan memupuk dan memperkukuh identiti diri serta semangat setia negara sebagai warganegara Malaysia yang arif dan peka Sejarah dapat dicapai (PPK, 2016). Hal ini demikian kerana aplikasi kemahiran-kemahiran belajar utama melalui pembelajaran abad ke-21 atau kemahiran $4 \mathrm{~K}$ seperti kemahiran komunikasi, kemahiran kretaiviti, kemahiran pemikiran kritis dan kemahiran kreativiti mampu dalam melahirkan murid yang berdaya saing pada peringkat global, di samping dapat mengangkat martabat sistem pendidikan Malaysia ke peringkat dunia (KPM, 2013). Justeru, pelbagai teknik dan bahan pembelajaran perlu dilaksanakan oleh guru-guru dalam proses pembelajaran dan pemudahcaraan yang menarik dan inovatif di dalam kelas bagi membolehkan murid dapat menguasai pengetahuan, kemahiran dan nilai seperti yang disarankan dalam kurikulum standard (Pusat Perkembangan Kurikulum (PPK, 2016).

\section{Pernyataan Masalah}

Adalah tidak dapat disangkal bahawa perkembangan pesat dalam bidang teknologi telah memudahkan pelaksanaan pembelajaran abad ke-21 melalui proses pembelajaran dalam atau luar talian dengan menggunakan pelbagai platform pembelajaran atau sistem pengurusan pembelajaran (Learning Management System) secara terbuka dan percuma yang mempunyai manfaatnya tersendiri dalam proses penyampaian dan pembentukan pengetahuan dan kemahiran yang merentasi tanpa sempadan dalam era globalisasi ini (Noradilah \& Lai, 2019). Rentetan daripada itu, penggunaan platform Google Classroom kini telah mula mendapat sambutan yang baik dalam kalangan guru bagi menjana kemenjadian murid serta meningkatkan kualiti pembelajaran yang lebih baik (Nurfayanti \& Nurbaeti, 2019; Ula Nisa, Lilis \& Trisnendri, 2019). Justeru, perkembangan penggunaan platform Google Classroom dan pembelajaran abad ke-21 telah mencadangkan kepada pengkaji untuk melaksanakan proses pembelajaran dan pemudahcaraan mata pelajaran sejarah yang bermakna yang dapat membentuk perspektif yang baik serta dapat menarik perhatian dan minat terhadap proses pembelajaran dalam kalangan murid selaras dengan murid-murid kini yang tergolong sebagai generasi $\mathrm{Z}$ yang terdedah dengan pelbagai gajet dan media yang interaktif. Keperluan untuk melaksanakan aktiviti pembelajaran sejarah berasaskan penggunaan platform Google Classroom dan aplikasi kemahiran $4 \mathrm{~K}$ dalam kajian ini adalah seiring dengan dapatan kajian Fitriningtiyas, Umamah dan Sumard (2018) dan kajian Sugiarto dan Aman (2020) yang telah melaporkan bahawa potensi penggunaan aplikasi Google Classroom sebagai media pembelajaran efektif dalam mata pelajaran sejarah. Sungguhpun begitu, murid-murid sering kali bertanggapan bahawa proses pembelajaran mata pelajaran sejarah membosankan dan tidak menarik (Lezah@Lejah \& Rosy, 2018) telah menimbulkan 
terdapat satu ruang kepada pengkaji untuk mengkaji persepsi murid terhadap proses pembelajaran mereka. Maka, kajian ini adalah bertujuan untuk mengenal pasti tahap persepsi murid terhadap pelaksanaan aktiviti pembelajaran sejarah melalui penggunaan platform Google Classroom dan aplikasi kemahiran $4 \mathrm{~K}$.

\section{Objektif Kajian}

Objektif kajian ini ialah:

i. Mengenal pasti tahap persepsi murid terhadap pelaksanaan aktiviti pembelajaran sejarah melalui penggunaan platform Google Classroom dan aplikasi kemahiran 4K.

ii. Mengenal pasti tahap persepsi murid terhadap pelaksanaan aktiviti pembelajaran sejarah melalui penggunaan platform Google Classroom dan aplikasi kemahiran 4K berdasarkan jantina.

iii. Mengenal pasti sama ada terdapat perbezaan min bagi persepsi murid terhadap pelaksanaan aktiviti pembelajaran sejarah melalui penggunaan platform Google Classroom dan aplikasi kemahiran $4 \mathrm{~K}$ berdasarkan jantina.

\section{Soalan Kajian}

Soalan kajian ini ialah:

i. pakah tahap persepsi murid terhadap pelaksanaan aktiviti pembelajaran sejarah melalui penggunaan platform Google Classroom dan aplikasi kemahiran 4K?

ii. Apakah tahap persepsi murid terhadap pelaksanaan aktiviti pembelajaran sejarah melalui penggunaan platform Google Classroom dan aplikasi kemahiran 4K berdasarkan jantina?

iii. Adakah terdapat perbezaan $\min$ bagi persepsi murid terhadap pelaksanaan aktiviti pembelajaran sejarah melalui penggunaan platform Google Classroom dan aplikasi kemahiran $4 \mathrm{~K}$ berdasarkan jantina?

\section{Hipotesis Kajian}

Bagi menjawab soalan kajian 3, maka hipotesis kajian $\left(\mathrm{H}_{\mathrm{o}}\right)$ telah dibentuk dan diuji pada tahap kesignifikan $p=0.05$ iaitu:

$\mathrm{H}_{\mathrm{o} 1}$ : Tidak terdapat perbezaan min yang signifikan bagi persepsi murid terhadap pelaksanaan aktiviti pembelajaran sejarah melalui penggunaan platform Google Classroom dan aplikasi kemahiran 4K berdasarkan jantina.

\section{Tinjauan Literatur}

\section{Platform Google Classroom}

Google Classroom merupakan aplikasi pembelajaran percuma yang telah dibangunkan oleh pihak Google untuk kegunaan sistem pendidikan pada tahun 2014 bagi memudahkan para pendidik merancang, melaksanakan dan mentaksirkan tugasan ataupun hasil kerja murid secara pendekatan paperless, di samping menggalakkan proses perkongsian bahan-bahan pembelajaran antara muridmurid dan guru-guru dengan membentuk komuniti persekitaran pembelajaran atas talian (Ade, 2018; Andri, 2016; Ken, Chris \& Gay, 2016; Joko \& Kartono, 2019; Sambit, 2020). Tambahan pula, platform Google Classroom ini telah menggabungkan aplikasi-aplikasi dalam Google itu sendiri seperti Google Drive, Google Docs, Google Sheets, Google Slide, Google Calendar, Gmail dan 
sebagainya, di samping pautan aplikasi-aplikasi lain seperti Quizizz, Kahoot, Quizlet, Plickers, EdPuzzle dan sebagainya yang melibatkan fungsi aplikasi sebagai rangkaian sosial, sebagai alat perkongsian bahan, sebagai papan pembelajaran interaktif, sebagai penyimpanan data dan sebagai penyediaan latihan pengukuhan (Mohd Amin, 2013; Ahmad Fkrudin, Wan Norma \& Nor Khayati, 2019; Muhammad Alif \& Sanimah, 2019).

\section{Kemahiran $4 K$}

Kemahiran abad ke-21 ataupun lebih dikenali sebagai kemahiran $4 \mathrm{~K}$ mempunyai satu set standard kemahiran yang khusus yang perlu diterapkan secara menyeluruh dalam kalangan murid melalui kandungan teras dan tema, kurikulum, standard dan pentaksiran, pembangunan profesional dan persekitaran pembelajaran (Patnership For $21^{\text {st }}$ Century Skills, 2006). Aplikasi kemahiran $4 \mathrm{~K}$ mempunyai kekuatan yang tersendiri dalam menyokong keberkesanan pelaksanaan proses pembelajaran dan pemudahcaraan bagi membolehkan murid-murid dapat membentuk kemahiran hidup dan kerjaya untuk bersaing pada peringkat global (Kementerian Pendidikan Malaysia, [KPM], 2014, 2015; Partnership for $21^{\text {st }}$ Century Skills, 2009; PPK, 2016). Terdapat empat kemahiran 4K yang utama yang perlu difokuskan dalam aspek proses pembelajaran dalam kalangan murid iaitu:

i. Kemahiran komunikasi (communication) merujuk kepada proses pertukaran maklumat daripada murid kepada murid yang lain.

ii. Kemahiran pemikiran kritis (critical thinking) merujuk kepada keupayaan murid untuk membuat penilaian mengenai sesuatu perkara.

iii. Kemahiran kreativiti (creativity) merujuk kepada proses penghasilan sesuatu yang baharu, berguna dan berkualiti.

iv. Kemahiran kolaborasi (collaboration) merujuk kepada sesuatu perkara yang dilakukan secara berkumpulan.

\section{Metod Kajian}

Kajian berbentuk tinjauan ini adalah melibatkan seramai 41 orang murid tingkatan dua sebagai sampel kajian ini yang telah dipilih melalui teknik persampelan berkelompok. Instrumen kajian ini merupakan soal selidik dengan skala likert 5 mata yang telah disahkan oleh pakar penilai dan mempunyai nilai kebolehpercayaan yang baik iaitu 0.85 (Nunnally, 1978). Data kajian ini telah dianalisis secara deskriptif iaitu min dan sisihan piawai dan statistik inferensi iaitu ujian- $t$ bagi sampel tak bersandar melalui perisian IBM SPSS versi 24. Tinjauan ini telah dijalankan bagi murid-murid yang telah mengikuti aktiviti pembelajaran sejarah melalui penggunaan platform Google Classroom dan aplikasi kemahiran $4 \mathrm{~K}$ bagi topik Kerajaan Kedah, Kelantan, Negeri Sembilan dan Perlis. Interpretasi tahap persepsi murid dalam kajian ini telah ditentukan melalui interpretasi tahap yang telah diberikan oleh Jamil Ahmad (2002) seperti ditunjukkan pada Jadual 1.

Jadual 1: Interpretasi Min dan Tahap

\begin{tabular}{cc}
\hline Skor Min & Tahap \\
\hline $3.67-5.00$ & Tinggi \\
$2.34-3.66$ & Sederhana \\
$1.00-2.33$ & Rendah \\
\hline
\end{tabular}

\section{Dapatan Kajian}

\section{Apakah tahap persepsi murid terhadap pelaksanaan aktiviti pembelajaran sejarah melalui penggunaan platform Google Classroom dan aplikasi kemahiran $4 \mathrm{~K}$ ?}

Berdasarkan Jadual 2, tahap persepsi murid terhadap pelaksanaan aktiviti pembelajaran sejarah melalui penggunaan platform Google Classroom dan aplikasi kemahiran $4 \mathrm{~K}$ adalah tinggi $(M=3.88$, 
$S D=0.62)$. Dari segi item pula, min bagi item "Aktiviti pembelajaran bernilai" $(M=4.29, S D=0.75)$ dilaporkan paling tinggi dalam kajian ini. Seterusnya, diikuti dengan item "Seronok mengikuti aktiviti pembelajaran" $(M=4.20, S D=0.87)$ dan item "Berpendapat menarik" $(M=4.20, S D=0.81)$, item "Menggambarkan seronok" $(M=4.17, S D=0.74)$, item "Aktiviti pembelajaran sangat menarik" $(M=4.15, S D=0.86)$, item "Sanggup melakukan lagi" $(M=4.12, S D=0.98)$, item "Penting untuk kemajuan diri" $(M=4.02, S D=0.85)$, item "Mengikut kemahuan" $(M=4.02, S D=0.96)$, item "Aktiviti pembelajaran berguna" $(M=3.95, S D=1.07)$, item "Terfikir betapa seronoknya" $(M=3.95, S D=0.97)$, item "Pilihan saya" $(M=3.83, S D=0.89)$ dan item "Aktiviti pembelajaran tidak bosan" $(M=3.73$, $S D=1.43$ ) yang kesemua item tersebut dilaporkan berada pada tahap tinggi. Walau bagaimanapun, terdapat tiga item dalam kajian ini yang telah dilaporkan berada pada tahap sederhana iaitu item "Tidak dipaksa" $(M=3.49, S D=1.38)$, item "Berasa melakukan apa yang diingini" $(M=3.17, S D=1.18)$ dan item "Terdapat pilihan lain" $(M=3.05, S D=1.43)$. Justeru, dapat dirumuskan bahawa tahap persepsi murid terhadap pelaksanaan aktiviti pembelajaran sejarah melalui penggunaan platform Google Classroom dan aplikasi kemahiran 4K adalah tinggi dalam kajian ini.

Jadual 2: Persepsi Murid Terhadap Pelaksanaan Aktiviti Pembelajaran Sejarah

\begin{tabular}{llll}
\hline Item & Min $(\boldsymbol{M})$ & $\begin{array}{l}\text { Sisihan } \\
\text { Piawai } \\
(\boldsymbol{S D})\end{array}$ & Tahap \\
\hline Terfikir betapa seronoknya & & 0.97 & Tinggi \\
Aktiviti pembelajaran bernilai & 3.95 & 0.75 & Tinggi \\
Pilihan saya & 3.29 & 0.89 & Tinggi \\
Aktiviti pembelajaran berguna & 3.95 & 1.07 & Tinggi \\
Aktiviti pembelajaran sangat menarik & 4.15 & 0.86 & Tinggi \\
Penting untuk kemajuan diri & 4.02 & 0.85 & Tinggi \\
Seronok mengikuti aktiviti pembelajaran & 4.20 & 0.87 & Tinggi \\
Tidak dipaksa & 3.49 & 1.38 & Sederhana \\
Aktiviti pembelajaran tidak bosan & 3.73 & 1.43 & Tinggi \\
Berasa melakukan apa yang diingini & 3.17 & 1.18 & Sederhana \\
Berpendapat menarik & 4.20 & 0.81 & Tinggi \\
Sanggup melakukan lagi & 4.12 & 0.98 & Tinggi \\
Terdapat pilihan lain & 3.05 & 1.43 & Sederhana \\
Menggambarkan seronok & 4.17 & 0.74 & Tinggi \\
Mengikut kemahuan & 4.02 & 0.96 & Tinggi \\
Bantu dalam aktiviti pembelajaran lain & 3.73 & 1.18 & Tinggi \\
\hline Keseluruhan & 3.88 & 0.62 & Tinggi \\
\hline
\end{tabular}

\section{Apakah tahap persepsi murid terhadap pelaksanaan aktiviti pembelajaran sejarah melalui penggunaan platform Google Classroom dan aplikasi kemahiran $4 \mathrm{~K}$ berdasarkan jantina?}

Berdasarkan Jadual 3, tahap persepsi murid terhadap pelaksanaan aktiviti pembelajaran sejarah melalui penggunaan platform Google Classroom dan aplikasi kemahiran 4K adalah tinggi bagi murid lelaki $(M=3.73, S D=0.74)$ dan murid perempuan $(M=3.95, S D=0.56)$. Sungguhpun begitu, min bagi persepsi murid perempuan adalah dilaporkan lebih tinggi terhadap pelaksanaan aktiviti pembelajaran sejarah melalui penggunaan platform Google Classroom dan aplikasi kemahiran 4K berbanding dengan murid lelaki dalam kajian ini. Dari segi item pula, murid lelaki telah melaporkan bahawa min bagi item "Aktiviti pembelajaran bernilai" $(M=4.23, S D=0.73)$ dan item "Aktiviti pembelajaran tidak bosan" ( $M=4.23, S D=0.83)$ adalah paling tinggi dalam kajian ini. Seterusnya, diikuti dengan item "Menggambarkan seronok" $(M=4.08, S D=0.86)$, item "Seronok mengikuti aktiviti pembelajaran $(M=4.00, S D=1.00)$, item "Berpendapat menarik" $(M=4.00, S D=0.82)$, item "Sanggup melakukan lagi" $(M=4.00, S D=1.22)$, item "Aktiviti pembelajaran sangat menarik" $(M=3.85, S D=1.07)$, item "Penting untuk kemajuan diri" $(M=3.85, S D=0.99)$, item "Mengikut kemahuan" $(M=3.85, S D=0.80)$, item "Aktiviti pembelajaran berguna" $(M=3.77, S D=1.30)$ dan item "Terfikir betapa seronoknya" $(M=3.69, S D=0.95)$ yang kesemua item tersebut dilaporkan berada pada tahap tinggi dalam kajian ini. 
Walau bagaimanapun, terdapat empat item yang telah dilaporkan berada pada tahap sederhana oleh murid-murid lelaki dalam kajian ini iaitu "Pilihan saya" $(M=3.62, S D=0.96)$, item "Tidak dipaksa" $(M=3.62, S D=1.26)$, item "Berasa melakukan apa yang diingini" $(M=2.62, S D=1.26)$ dan item "Terdapat pilihan lain" $(M=2.54, S D=1.45)$. Justeru, dapat dirumuskan bahawa tahap persepsi murid lelaki terhadap pelaksanaan aktiviti pembelajaran sejarah berasaskan penggunaan platform Google Classroom dan aplikasi kemahiran 4K berada pada tahap tinggi dalam kajian ini.

Tambahan pula, min bagi item "Aktiviti pembelajaran bernilai" $(M=4.32, S D=0.77)$ dilaporkan berada pada tahap paling tinggi dalam kalangan murid perempuan dalam kajian ini. Seterusnya, diikuti dengan item "Aktiviti pembelajaran sangat menarik" $(M=4.29, S D=0.76)$, item "Seronok mengikuti aktiviti pembelajaran" $(M=4.29, S D=0.81)$, item "Berpendapat menarik" $(M=4.29, S D=0.81)$, item "Menggambarkan seronok" $(M=4.21, S D=0.69)$, item "Sanggup melakukan lagi" $(M=4.18, S D=0.86)$, item "Penting untuk kemajuan diri $(M=4.11, S D=0.79)$, item "Mengikut kemahuan" $(M=4.11$, $S D=1.03)$, item "Terfikir betapa seronoknya" $(M=4.07, S D=0.98)$, item "Aktiviti pembelajaran berguna" $(M=4.04, S D=0.96)$, item "Pilihan saya" $(M=3.93, S D=0.86)$ dan item "Bantu dalam aktiviti pembelajaran lain" $(M=3.75, S D=1.24)$ yang kesemua item tersebut dilaporkan berada pada tahap tinggi dalam kajian ini. Sungguhpun begitu, terdapat empat item dalam kajian ini yang telah dilaporkan berada pada tahap sederhana dalam kajian ini iaitu item "Tidak dipaksa" $(M=3.43$, $S D=1.45)$, item "Aktiviti pembelajaran tidak bosan $(M=3.50, S D=1.60)$, item "Berasa melakukan apa yang diingini" ( $M=3.43, S D=1.17)$ dan item "Terdapat pilihan lain" $(M=3.29, S D=1.38)$. Justeru, dapat dirumuskan bahawa tahap persepsi murid perempuan terhadap pelaksanaan aktiviti pembelajaran sejarah melalui penggunaan platform Google Classroom dan aplikasi kemahiran 4K berada pada tahap tinggi dalam kajian ini.

Jadual 3: Persepsi Murid Terhadap Pelaksanaan Aktiviti Pembelajaran Sejarah Berdasarkan Jantina

\begin{tabular}{|c|c|c|c|c|c|c|}
\hline \multirow[t]{2}{*}{ Item } & \multicolumn{3}{|c|}{ Murid Lelaki $(N=13)$} & \multicolumn{3}{|c|}{ Murid Perempuan $(N=28)$} \\
\hline & $\begin{array}{l}\text { Min } \\
(M)\end{array}$ & $\begin{array}{l}\text { Sisihan } \\
\text { Piawai } \\
(S D)\end{array}$ & Tahap & $\begin{array}{l}\text { Min } \\
(M)\end{array}$ & $\begin{array}{l}\text { Sisihan } \\
\text { Piawai } \\
\text { (SD) }\end{array}$ & Tahap \\
\hline Terfikir betapa seronoknya & 3.69 & 0.95 & Tinggi & 4.07 & 0.98 & Tinggi \\
\hline Aktiviti pembelajaran bernilai & 4.23 & 0.73 & Tinggi & 4.32 & 0.77 & Tinggi \\
\hline Pilihan saya & 3.62 & 0.96 & Sederhana & 3.93 & 0.86 & Tinggi \\
\hline Aktiviti pembelajaran berguna & 3.77 & 1.30 & Tinggi & 4.04 & 0.96 & Tinggi \\
\hline $\begin{array}{l}\text { Aktiviti pembelajaran sangat } \\
\text { menarik }\end{array}$ & 3.85 & 1.07 & Tinggi & 4.29 & 0.76 & Tinggi \\
\hline Penting untuk kemajuan diri & 3.85 & 0.99 & Tinggi & 4.11 & 0.79 & Tinggi \\
\hline $\begin{array}{l}\text { Seronok mengikuti aktiviti } \\
\text { pembelajaran }\end{array}$ & 4.00 & 1.00 & Tinggi & 4.29 & 0.81 & Tinggi \\
\hline Tidak dipaksa & 3.62 & 1.26 & Sederhana & 3.43 & 1.45 & Sederhana \\
\hline $\begin{array}{l}\text { Aktiviti pembelajaran tidak } \\
\text { bosan }\end{array}$ & 4.23 & 0.83 & Tinggi & 3.50 & 1.60 & Sederhana \\
\hline $\begin{array}{l}\text { Berasa melakukan apa yang } \\
\text { diingini }\end{array}$ & 2.62 & 1.04 & Sederhana & 3.43 & 1.17 & Sederhana \\
\hline Berpendapat menarik & 4.00 & 0.82 & Tinggi & 4.29 & 0.81 & Tinggi \\
\hline Sanggup melakukan lagi & 4.00 & 1.22 & Tinggi & 4.18 & 0.86 & Tinggi \\
\hline Terdapat pilihan lain & 2.54 & 1.45 & Sederhana & 3.29 & 1.38 & Sederhana \\
\hline Menggambarkan seronok & 4.08 & 0.86 & Tinggi & 4.21 & 0.69 & Tinggi \\
\hline Mengikut kemahuan & 3.85 & 0.80 & Tinggi & 4.11 & 1.03 & Tinggi \\
\hline $\begin{array}{l}\text { Bantu dalam aktiviti } \\
\text { pembelajaran lain }\end{array}$ & 3.69 & 1.14 & Tinggi & 3.75 & 1.24 & Tinggi \\
\hline Keseluruhan & 3.73 & 0.74 & Tinggi & 3.95 & 0.56 & Tinggi \\
\hline
\end{tabular}




\section{Adakah terdapat perbezaan min persepsi murid terhadap pelaksanaan aktiviti pembelajaran sejarah melalui penggunaan platform Google Classroom dan aplikasi kemahiran $4 \mathrm{~K}$ berdasarkan jantina?}

Hipotesis kajian:

$\mathrm{H}_{\mathrm{ol}}$ : Tidak terdapat perbezaan min yang signifikan bagi persepsi murid terhadap pelaksanaan aktiviti pembelajaran sejarah melalui penggunaan platform Google Classroom dan aplikasi kemahiran $4 \mathrm{~K}$ berdasarkan jantina.

Berdasarkan keputusan ujian Levene's yang tidak signifikan $(F=1.05, p=0.31)$, keputusan ujian-t sampel tak bersandar dalam Jadual 4 telah melaporkan bahawa tidak terdapat perbezaan min yang signifikan bagi persepsi murid terhadap pelaksanaan aktiviti pembelajaran sejarah melalui penggunaan platform Google Classroom dan aplikasi kemahiran 4K [ $t(39)=-1.08, p=0.29]$ berdasarkan jantina. Justeru, $\mathrm{H}_{\mathrm{ol}}$ telah gagal ditolak. Maka, dapat disimpulkan bahawa persepsi murid lelaki dan murid perempuan adalah sama terhadap pelaksanaan aktiviti pembelajaran sejarah melalui penggunaan platform Google Classroom dan aplikasi kemahiran 4K dalam kajian ini.

Jadual 4: Ujian-t

\begin{tabular}{|c|c|c|c|c|c|c|c|c|c|}
\hline & \multicolumn{7}{|c|}{ Ujian-t bagi persamaan min } & \multirow{2}{*}{\multicolumn{2}{|c|}{$\begin{array}{l}\text { 99\% selang } \\
\text { keyakinan bagi } \\
\text { perbezaan }\end{array}$}} \\
\hline & \multicolumn{2}{|c|}{$\begin{array}{l}\text { Ujian } \\
\text { Levene's }\end{array}$} & \multirow[t]{2}{*}{$t$} & \multirow[t]{2}{*}{$d f$} & \multirow[t]{2}{*}{$p$} & \multirow[t]{2}{*}{$\begin{array}{l}\text { Perbezaan } \\
\text { min }\end{array}$} & \multirow[t]{2}{*}{$\begin{array}{l}\text { Min } \\
\text { ralat } \\
\text { Piawai }\end{array}$} & & \\
\hline & $\boldsymbol{F}$ & $p$ & & & & & & Bawah & Atas \\
\hline Perbezaan Min & 1.05 & 0.31 & -1.08 & 39 & 0.29 & -0.22 & 0.21 & -0.65 & 0.20 \\
\hline
\end{tabular}

\section{Perbincangan Kajian}

Dapatan kajian ini yang menunjukkan bahawa tahap persepsi terhadap pelaksanaan aktiviti pembelajaran sejarah melalui penggunaan platform Google Classroom dan aplikasi kemahiran 4K yang berada pada tahap tinggi dalam kalangan murid secara keseluruhannya dan termasuk dalam kalangan lelaki dan murid perempuan adalah sealiran dengan dapatan kajian yang dijalankan oleh Harefa dan Sumiyati (2020) yang telah melaporkan bahawa sebanyak 40.54 peratus murid tertarik dengan pelaksanaan aktiviti pembelajaran Kimia yang berbantukan aplikasi Google Classroom di SMA Abdi Siswa Tangerang yang melibatkan seramai 74 orang murid dari kelas X IPA dan kelas XI IPA. Tahap persepsi yang tinggi yang telah dilaporkan dalam kajian ini adalah disebabkan muridmurid berasa seronok dengan aktiviti pembelajaran yang bersifat minds on dan hands on yang berteraskan dengan penggunaan teknologi melalui platform Google Classroom yang dapat membentuk suasana pembelajaran yang menarik dan interaktif. Pendapat ini adalah bertepatan dengan dapatan kajian Joinis, Tan dan Sabariah Sharif (2018), kajian Nurul Hafizah, Norfiza, Nurul Suzaina dan Rorlinda (2020) serta dapatan kajian Kaviza (2019) yang telah melaporkan bahawa tahap persepsi penerimaan murid terhadap proses pembelajaran sejarah melalui penggunaan blog forum sejarah, penggunaan permainan ITRACK dan pelaksanaan Model Flipped Classroom Peer Instruction adalah tinggi dan positif yang telah menyokong dapatan kajian ini secara langsung mahupun secara tidak langsung. Tambahan pula, dapatan kajian ini yang menunjukkan bahawa tidak terdapat perbezaan min yang signifikan bagi persepsi murid terhadap pelaksanaan aktiviti pembelajaran sejarah melalui penggunaan platform Google Classroom dan aplikasi kemahiran 4K berdasarkan jantina adalah konsisten dengan dapatan kajian Nur Syazwani, Mohd Mahzan, Kamarulzaman dan Nur Azuki (2019), kajian Rossafri dan Wan Ahmad (2007), kajian Mohd Johari (2017) dan kajian Oppong (2013) yang juga telah melaporkan bahawa min persepsi murid lelaki dan perempuan terhadap penggunaan multimedia, penggunaan filem dan penggunaan item aneka pilihan dalam proses pembelajaran sejarah adalah tidak berbeza dengan signifikan. Justeru, dapat dirumuskan bahawa tahap persepsi murid terhadap pelaksanaan aktiviti pembelajaran sejarah melalui penggunaan platform Google Classroom dan aplikasi kemahiran $4 \mathrm{~K}$ adalah berada pada tahap tinggi dalam kajian ini. 


\section{Kesimpulan}

Kesimpulannya, dapatan kajian ini telah melaporkan bahawa tahap persepsi murid terhadap pelaksanaan aktiviti pembelajaran sejarah melalui penggunaan platform Google Classroom dan aplikasi kemahiran 4K adalah tinggi secara keseluruhannya. Selain itu, tahap persepsi murid terhadap pelaksanaan aktiviti pembelajaran sejarah melalui penggunaan platform Google Classroom dan aplikasi kemahiran $4 \mathrm{~K}$ juga dilaporkan berada pada tahap tinggi dalam kalangan murid lelaki dan murid perempuan. Walau bagaimanapun, dapatan kajian ini telah melaporkan bahawa tidak terdapat perbezaan min yang signifikan bagi persepsi murid terhadap pelaksanaan aktiviti pembelajaran sejarah melalui penggunaan platform Google Classroom dan aplikasi kemahiran 4K berdasarkan jantina. Justeru, implikasi kajian ini telah mencadangkan agar semua pihak perlu memainkan peranan dalam melaksanakan proses pembelajaran sejarah yang lebih berkesan dan bermakna melalui penggunaan platform Google Classroom dan aplikasi kemahiran 4K selaras dengan menyahut saranan dasar pendidikan yang menekankan keperluan dan kepentingan penerapan pembelajaran abad ke-21 dan pengintegrasian teknologi dalam proses pengajaran dan pembelajaran pada semua peringkat persekolahan (KPM, 2013, 2016).

\section{Rujukan}

Ade, C. P.J. (2018). Development of science learning tool based on problem based learning with google classroom to improve argumentative skill. Biosaintifika, 10(2), 348-355.

Ahmad Fkrudin Mohamed Yusoff, Wan Norma Wan Hamat \& Nor Khayati Basir (2019). Penggunaan aplikasi web 2.0 dalam proses pengajaran dan pembelajaran kursus mata pelajaran umum (MPU) di politeknik. E-Bangi, 16(5), 1-13.

Andri, W. (2016). Analysis of factors affecting the use of google classroom to support lectures. Kertas kerja yang dibentangkan di $5^{\text {th }}$ International Conference on Information Technology and Engineering Application Palembang-Indonesia, 19-20 Februari 2016.

Fitriningtiyas, D.A., Umamah, N.S \& Sumardi. (2018). Google Classroom: as a media of learning history. ICEGE 2018: Conferences Earth and Environment Science, 1-8.

Jamil Ahmad. (2002). Pemupukan Budaya Penyelidikan di Kalangan Guru di Sekolah: Satu Penilaian. Tesis Ijazah Kedoktoran, Fakulti Pendidikan: Universiti Kebangsaan Malaysia

Joinis Longkiad, Tan, C.K., \& Sabariah Sharif. (2018). Kesan penggunaan blog forum sejarah terhadap penerimaan teknologi dan pencapaian pelajar sejarah di sebuah sekolah menengah di daerah Keningau. Jurnal Sultan Alauddin Sulaiman Shah (Special Issues), 183-200.

Joko, S., \& Kartono, Z.M (2019). Analysis metacognition and communication mathematics in blended learning use google classroom. Unnes Journal of Mathematics Education Research, 8(1), 72-83.

Kaviza, M. (2019). Tahap Persepsi Penerimaan Murid Terhadap Pelaksanaan Model Flipped Classroom Peer Instruction dalam Mata Pelajaran Sejarah. Attarbawiy: Malaysian Online Journal of Education, 3(2), 30-47.

Kementerian Pendidikan Malaysia. (2013). Pelan Pembangunan Pendidikan Malaysia 2013-2025. Putrajaya: Kementerian Pendidikan Malaysia.

Ken, E, Chris, G \& Guy, S. (2016). Google classroom: The nuts and Bolts of getting your strated. FD Newletter, 21(1), 2-21.

Lezah @ Lejah Kiamsin \& Rosy Talin. (2018). Kaedah pengajaran sejarah yang diminati pelajar dan justifikasinya. Malaysian Journal of Social Sciences and Humanities, 3(2), 137-145.

Mohamed Amin Embi. (2013). Web 2.0 Interactive Tools: A Quick Guide. Bangi: UKM

Mohd Johari Hassan (2017). Persepsi murid terhadap pembelajaran melalui filem dan penerapan kemahiran pemikiran sejarah. Kertas kerja yang dibentangkan di International Conference on Global Education V Global Education, Common Wealth and Cultural Diversity, 10-11 Aril 2017, Universiti Eksalaiti, Padang Indonesia.

Muhammad Alif Redzuan Abdullah \& Sanimah Hussin (2019). Sikap dan persepsi pelajar terhadap penggunaan aplikasi web 2.0 dalam proses pengajaran dan pembelajaran Bahasa Jepun di Universitu Utara Putra Malaysia. Jurnal Linguistik, 23(1), 51-57.

Noradilah binti Aziz \& Lai, W.S. (2019). Impak Pendidikan Berasaskan Teknologi Terhadap Peningkatan Prestasi Pelajar di UKM. Jurnal Personalia Pelajar, 22(1), 69-75. 
Nunnally, J.C. (1978). Psychometrie Theory ( $2^{\text {nd }}$ ed.). New York: McGraw Hill.

Nur Syazwani Abdul Talib, Mohd Mahzan Awang, Kamarulzaman Abdul Ghani \& Nur Azuki Yusuff (2019). Penggunaan multimedia dalam mata pelajaran sejarah. INSANIAH: Online Journal of Language, Communication and Humanities, 2(2), 76-88.

Nurfayanti \& Nurbaeti (2019). Pengaruh media pembelajaran Google Classroom dalam pembelajaran analisis real terhadap motivasi belajar mahasiswa. Jurnal Penelitian Matematika dan Pendidikan Matematika, 2(1), 50-59.

Nurul Hafizah Maarof, Norfiza Apfandi, Nurul Suzaina Joli \& Rorlinda Yusof (2020). ITRACK dalam PDP Sejarah: Tinjauan terhadap motivasi pelajar. International Journal of Education and Pedagogy, 2(1), 83-97.

Oppong, C.A. (2013). Gender differences in student's performance in history of senior high school in Cape Coast. Journal of Arts and Humanities, 2(1), 34-39.

Partnership for 21st Century Skills. (2006). Framework for 21st century learning. Retrieved from http://www.p21.org/documents/ProfDev.pdf

Pusat Perkembangan Kurikulum. (2016). Dokumen Standard Kurikulum dan Pentaksiran Mata Pelajaran Sejarah Tingkatan Dua. Putrajaya: Kementerian Pendidikan Malaysia.

Rossafri Mohamad \& Wan Ahmad Jaafar Wan Yahya. (2007). Impak Bahan Multimedia ke atas mata pelajaran berbentuk naratif: Satu kajian terhadap mata pelajaran sejarah. Prosiding $1^{s t}$ International Malaysia Educational Technology Convention, 920-929.

Sambit, D. (2020). Google classroom as learning management system to teach Biochemistry in a medical school. Biochemistry and Molecular Biology Education, 1-4.

Sugiarto, R \& Aman. (2020). The ultization of Google Classroom in implementing Distance Learning in Islamic High School al-Azhar 9 of Yogyarkata during Covid-19 Pandemic. Proceeding of Annual International Conference on Social Science and Humanities (AICOSH 2020), 100-104.

Ula, N.El.F, Lilis, S \& Trisnendri, S. (2019). Penerapan Google Classroom dalam pembelajaran Inggeris kepada guru bahasa Inggeris SMP di Subang. Jurnal Pengabdian kepada Masyarakat (Abdimus), 2(2), 183-191. 